\title{
Gigantic aneurysm of a venous bypass graft causing superior vena cava syndrome
}

\author{
Karol S. Buszkiewicz ${ }^{1,2}$, Paweł Bugajski ${ }^{1}$, Ryszard Kąsinowski ${ }^{3}$, Jaromir Furmaniuk ${ }^{3}$, Janusz Rzeźniczak ${ }^{4}$, \\ Tomasz Poprawka1 ${ }^{1}$, Ireneusz Jedliński ${ }^{5}$, Krzysztof Greberski ${ }^{1,2}$, Ryszard Kalawski ${ }^{1,2}$ \\ ${ }^{1}$ Oddział Kardiochirurgii z Salami Intensywnego Nadzoru Kardiologicznego, Wielospecjalistyczny Szpital \\ Miejski im. J. Strusia w Poznaniu \\ ${ }^{2}$ Zakład Profilaktyki Chorób Układu Krążenia, Uniwersytet Medyczny im. Karola Marcinkowskiego w Poznaniu \\ ${ }^{3}$ Oddział Kardiologii Inwazyjnej i Chorób Wewnętrznych z Pododdziałem Intensywnej Opieki Kardiologicznej \\ Szpitala Wojewódzkiego w Poznaniu \\ ${ }^{4}$ Oddział Kardiologii, Wielospecjalistyczny Szpital Miejski im. J. Strusia w Poznaniu \\ ${ }^{5}$ Pracownia Nieinwazyjnej Diagnostyki Chorób Serca i Naczyń, Szpital Miejski im. J. Strusia w Poznaniu \\ Kardiochirurgia i Torakochirurgia Polska 2014; 11 (1): 71-75
}

\begin{abstract}
A case of a 66-year-old patient 13 years after coronary artery bypass grafting (CABG) admitted to hospital with typical ischemic chest pain and symptoms of superior vena cava syndrome (SVCS) is described. Non-invasive diagnostics confirmed acute coronary syndrome: non-ST-elevated myocardial infarction (ACS NSTEMI). Trans-thoracic echocardiography (TTE) revealed a gigantic tumor mass modeling the right atrium, causing chronic cardiac tamponade. Angiography showed that the tumor mass was in fact the aneurysmatically changed venous bypass graft to the right coronary artery (RCA). Computed tomography angiography (CT-angio) confirmed venous aneurysm size (the longest diameters were $10.2 \mathrm{~cm} \times 8.7 \mathrm{~cm}$ ). We also present treatment planning and the aneurysmal surgical removal procedure of this very rare case.
\end{abstract}

Key words: coronary artery bypass grafting (CABG), superior vena cava syndrome (SVCS), venous graft aneurysm.

\section{Introduction}

Since the groundbreaking study by Favaloro was published in 1968, the use of the great saphenous vein for coronary artery bypass grafting (CABG) has become a standard in the surgical treatment of ischemic heart disease [1]. In Poland, the first surgery involving direct cardiac revascularization was conducted by Jan Moll as soon as 1970 .

The saphenous vein remains the most frequently used material for coronary artery bypass grafting, even though numerous studies indicate that arterial revascu-

\section{Streszczenie}

W pracy przedstawiono przypadek 66-letniego pacjenta 13 lat po pomostowaniu aortalno-wieńcowym (CABG), przyjętego do szpitala rejonowego z nasilającymi się objawami dławicy piersiowej i zespołu żyły głównej górnej. Dalsza diagnostyka nieinwazyjna potwierdziła rozpoznanie ostrego zespołu wieńcowego bez uniesienia odcinka ST (OZW NSTEMI). Echokardiografia przezklatkowa uwidoczniła obecność ogromnej masy guza modelującego prawy przedsionek, dającego także cechy przewlekłej tamponady serca. Koronarografia i angiografia pomostów wykazały, że jest to zmieniony tętniakowato pomost żylny do jednej z gałęzi prawej tętnicy wieńcowej. Tomografia naczyniowa z programem naczyniowym pozwoliła na oszacowanie wielkości tworu (największy wymiar 10,2 cm × 8,7 cm). W dalszej części pracy omówiono szczegółowo postępowanie lecznicze tego rzadkiego przypadku tętniaka pomostu żylnego, w tym zabieg chirurgiczny jego usunięcia.

Słowa kluczowe: pomostowanie aortalno-wieńcowe, zespół żyły głównej górnej, tętniak pomostu żylnego.

larization is of greater benefit to the patient, especially in long-term observation [2]. An increasing number of reports underscore the advantages of total arterial revascularization (TAR) over revascularization using mixed veno-arterial material [3]. In contrast to arteries used for bypass grafting, veins situated in high-pressure systems, such as the coronary circulation, often undergo accelerated degenerative changes. The pathological changes leading to adverse restructuring of the vascular autograft result in flow impairment, which may cause the develop-

Address for correspondence: Karol S. Buszkiewicz, Oddział Kardiochirurgii z Salami Intensywnego Nadzoru Kardiologicznego, Wielospecjalistyczny Szpital Miejski im. J. Strusia w Poznaniu, ul. Szkolna 8/12, 61-833 Poznań, phone: +48 696181 166, e-mail: karolbuszkiewicz@gmail.com 
ment of ectasia, thrombus, critical stenoses, or even loss of patency.

Repeat revascularization can be conducted either by performing a percutaneous coronary intervention or by repeating the CABG procedure; the choice of the treatment method depends on the location of the changes in the coronary arteries and bypasses, concomitant diseases, the general condition of the patient, and their preference concerning the treatment method. The decisions undertaken by the heart team with regard to post-CABG patients are particularly important.

\section{Aim of the study}

The aim of this study is to present the case of a patient operated on in 1999 due to a giant aneurysm of a venous aorto-coronary bypass presenting with symptoms of superior vena cava syndrome (SVCS).

\section{Material and methods}

The 66-year-old patient was referred from the regional hospital to the cardiac surgery ward in order to undergo treatment for a giant aneurysm developed on the basis of a degenerated venous aorto-coronary bypass, causing symptoms of superior vena cava syndrome and chronic pericardial tamponade.

Thirteen years earlier, the patient had undergone CABG at the same ward. During the procedure, four coronary bypasses were performed: one arterial LIMA-LAD and three venous: to the first marginal branch (LMRG I), second marginal branch (LMRG II), and right coronary artery (RCA) in the region of the posterior descending artery (PDA). The patient was later hospitalized twice, in 2000 and 2004, due to increasing anginal complaints - in both cases, conservative treatment resulted in the improvement of his clinical condition. The intensification of pharmacological treatment in

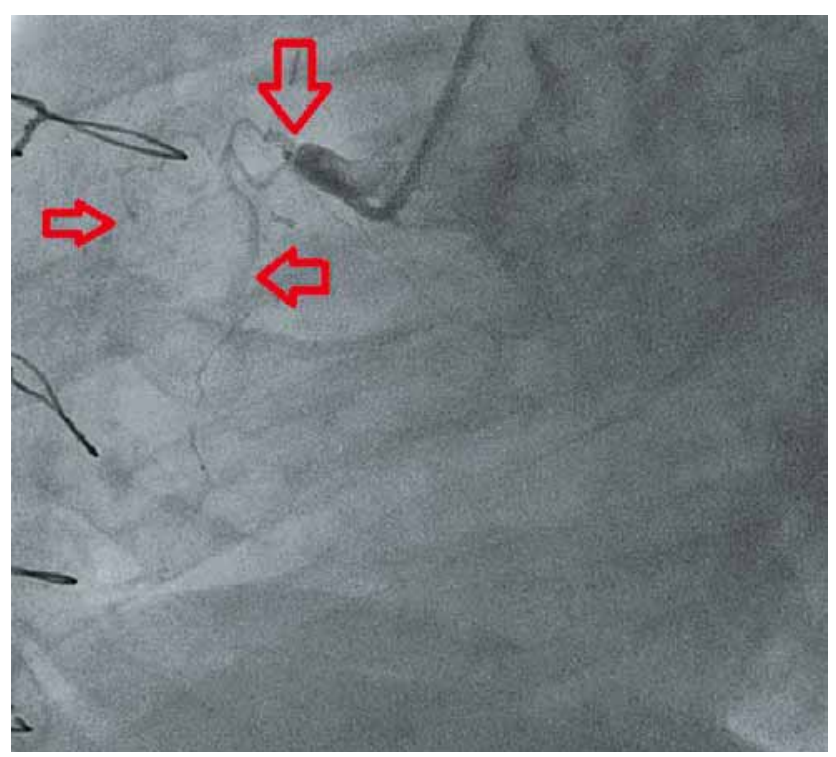

Fig. 1. RCA angiography (LAO 55.0 CAUD 1.9). Red arrows - aortic branching off of the RCA, visible lack of flow in the superior trunk, contrast limited to small branches the form of increasing doses of already used medications (a loop diuretic and a beta-blocker) and (during the second hospitalization) the introduction of new agents from other groups (a thiazide diuretic and a sartan) were effective enough for the patient to be referred for out-patient treatment.

In June 2012, the patient was hospitalized again at the internal diseases department of the regional hospital due to anginal complaints of significantly increased intensity. Based on physical examination, laboratory tests and clinical overview acute coronary syndrome without ST-segment elevation (ACS NSTEMI) was diagnosed; angiographic examinations of the coronary arteries and bypasses were conducted via femoral artery access. Angiography was hindered because of intensified atherosclerosis of lower-extremity arteries, but it revealed the occlusion of the RCA (Fig. 1), LAD, LMRG I, and LMRG II in segments proximal to the bypasses. Normal flow was visualized in the bypasses leading to the LAD, LMRG I, and LMRG II; when a critical constriction of the circumflex artery (CX) was revealed, therapy with the use of a bare metal stent (BMS) was applied.

The venous bypass to the right coronary artery was visualized in the form of a giant aneurysm, partially filled with contrast and situated next to the right atrium; the aneurysm was clearly exerting pressure on the atrium (Figs. 2 and 3). Based on transthoracic echocardiography, the size of the mass was estimated at approximately $6 \mathrm{~cm} \times 6 \mathrm{~cm}$. The presence of the aneurysm was confirmed by angio-CT, which revealed the presence of a hypodense lesion, modeling the right atrium (Figs. 4 and 5). The presence of pulmonary embolism, suspected due to significant dyspnea reported by the patient, was excluded. The patient was referred to the cardiac surgery ward for further treatment.

After admission, standard laboratory and imaging tests were performed. The examinations revealed that the D-dimer level was 6-fold higher than the norm $(3.07 \mu \mathrm{g} / \mathrm{ml}$, laboratory norm: up to $0.5 \mu \mathrm{g} / \mathrm{ml}$ ); the tests also demonstrated elevated levels of BNP (234 pg/ml, norm: up to $100 \mathrm{pg} / \mathrm{ml})$, urea $(7.8 \mathrm{mmol} / \mathrm{l}$, norm: 2.3-6.5 mmol/l), and creatinine $(120 \mu \mathrm{mol} / \mathrm{l}$, norm: $60-106 \mu \mathrm{mol} / \mathrm{l})$. The imaging examinations revealed the following: X-ray - enlarged shadow of the mediastinum, especially of the right cardiac contour; transthoracic echocardiography - the aforementioned characteristics of the discovered mass, generalized hypokinesis of the left ventricle, and a reduction in ejection fraction to approximately $20 \%$.

After the analysis of the examination results, a twostage invasive treatment was planned.

The first stage was conducted in the catheterization laboratory. Angiography of the coronary vessels and bypasses was conducted via right radial artery access. Multidirectional and non-functional flow was revealed during the evaluation of the venous bypass to the RCA. A balloon catheter (INVATEC Admiral Extreme PTA Balloon $4.0 \mathrm{~mm} \times 40 \mathrm{~mm} /$ $130 \mathrm{~cm}$ ) was introduced into the proximal segment of the bypass in order to prevent contrast regurgitation. Next, residual blood was aspirated from the aneurysm through 


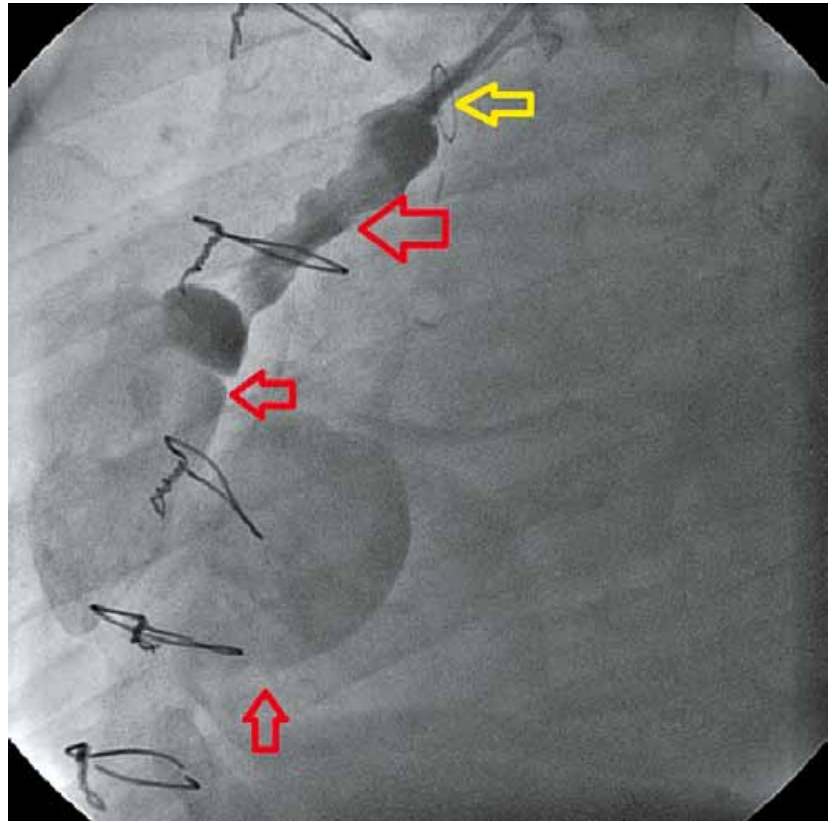

Fig. 2. Angiography of the venous bypass to the RCA (LAO 55.0 CAUD 1.9): red arrows - the initial segment of the bypass and the aneurysm located on its more distal segment. Yellow arrow a metal ring (marker) placed on the bypass during the initial CABG procedure to mark the aortic opening of the bypass

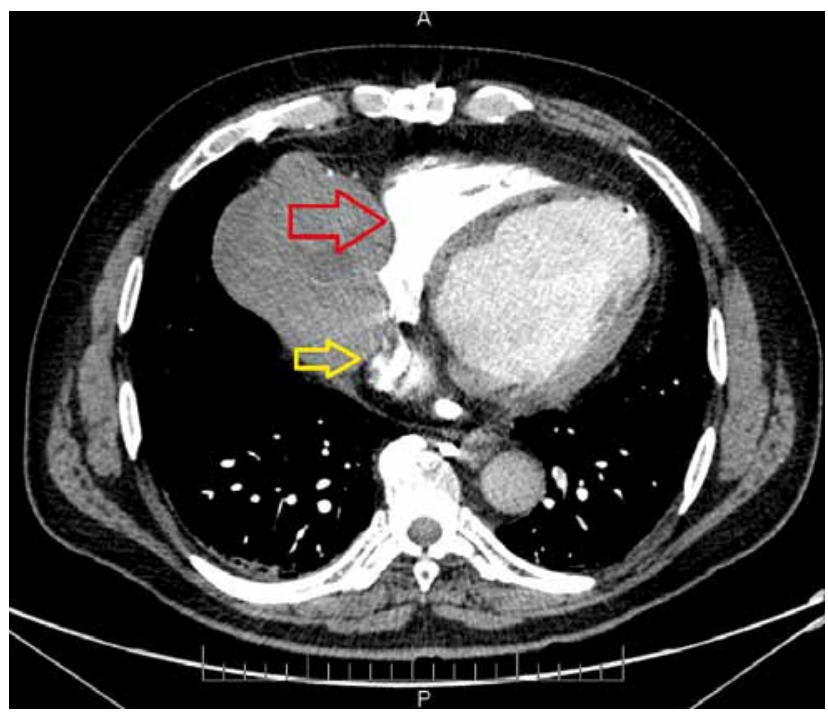

Fig. 4. The aneurysm pressing on the superior vena cava (red arrow) and, partially, on the right atrium (yellow arrow)

the catheter, and thrombin was administered (400 units, Biotrombina 400) in order to inhibit flow in the non-functioning bypass and to cause maximal clotting of the blood remaining inside. Angiographic control, conducted after 15 minutes, visualized an almost complete reduction of flow through the bypass affected by aneurysmal changes. A second balloon catheter was introduced (Quantum Maverick Monorail $5.0 \mathrm{~mm} \times 15 \mathrm{~mm}$ ) and placed in the aortic opening of the aneurysm, after which the patient was transferred to the operating room.

The second stage of treatment consisted in a surgical procedure. Due to the location of the lesion and the pres-

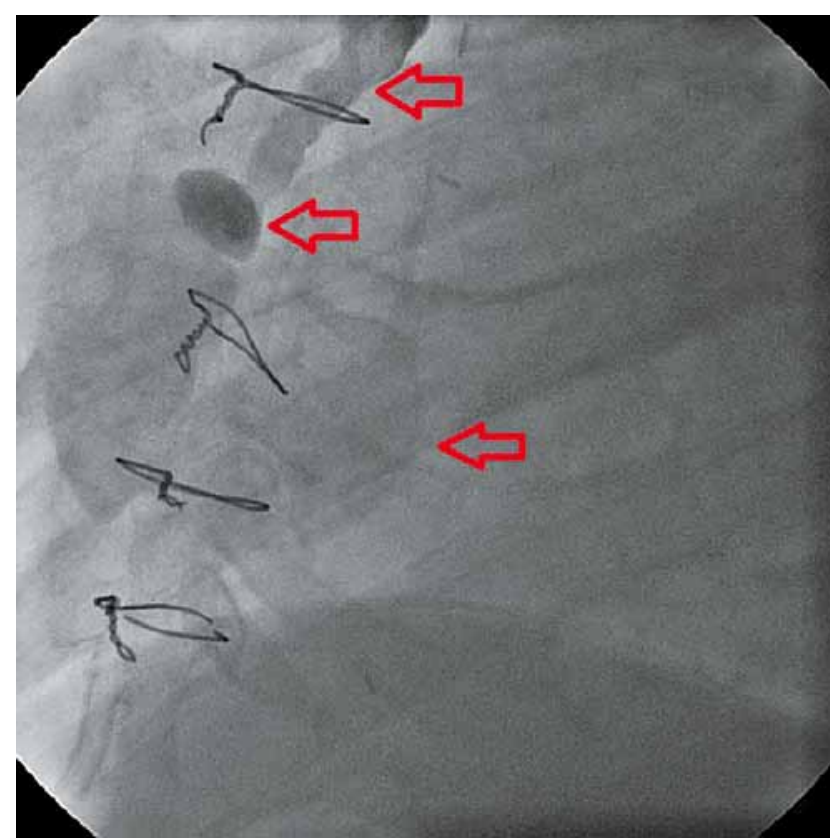

Fig. 3. Angiography of the venous bypass to the RCA (LAO 55.0 CAUD 1.9): red arrows - the venous bypass to the RCA affected by aneurysmal changes

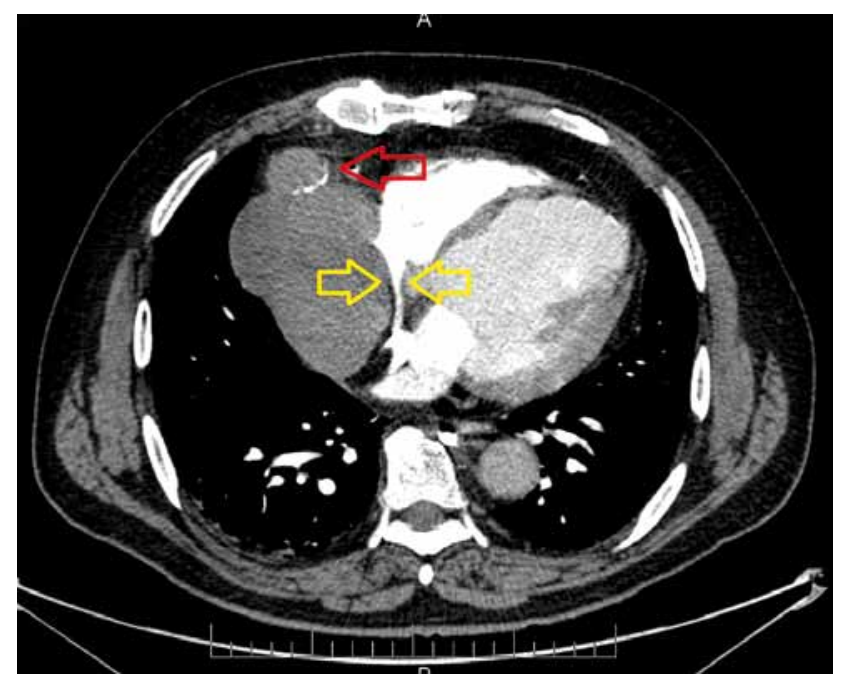

Fig. 5. The aneurysm with a fragment of the degenerated venous bypass (red arrow) and the visualized compressed superior vena cava (yellow arrows)

ence of three patent bypasses supplying the left coronary artery, right-sided thoracotomy (double-lumen intubation with right lung deflation) was selected as the access type, which enabled the visualization of the degenerated bypass. Thanks to the previous treatment stage and the use of thrombin, the risk of bleeding associated with mass rupture was significantly reduced.

The actual size of the largely visualized degenerated bypass was estimated at approximately $14 \mathrm{~cm} \times 12 \mathrm{~cm}$ (Fig. 6). The chronicity of the process of mass development was, paradoxically, a favorable circumstance, as it resulted in the creation of a pseudo-sac, which separated the formation from 


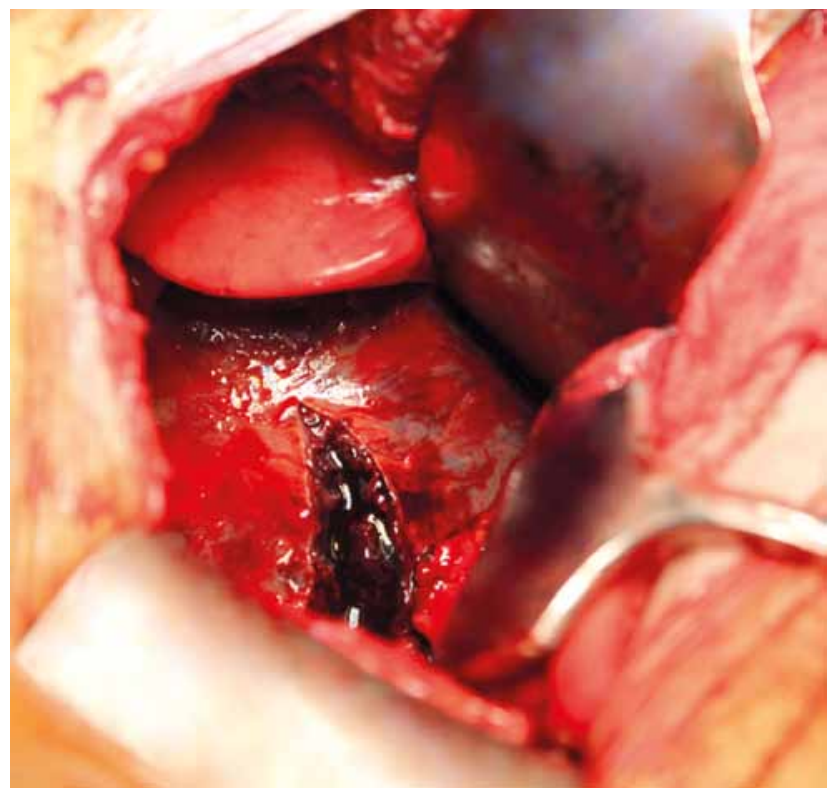

Fig. 6. The incised sac of the aneurysm of the degenerated venous bypass

the surrounding tissues. The total content of the removed aneurysm was assessed at approximately $600 \mathrm{~cm}^{3}$. Both ends of the bypass (proximal on the aorta and distal on the heart) were closed with pledget sutures (5-0 Prolene, Ethicon); next, the catheter remaining in the aortic orifice of the aneurysm was removed. Subsequent patient management included hemostatic control, the introduction of drains into the right pleural cavity, right lung expansion under visual control, and layered closure of the chest.

Unfortunately, during the described actions, as the patient's skin was being sutured, ventricular fibrillation occurred without any preceding symptoms. External defibrillation, performed multiple times, was unsuccessful. The patient's chest was immediately reopened, and internal defibrillation was attempted multiple times; these attempts also proved unsuccessful. During internal cardiac massage, which was hindered by adhesions around the heart from the initial CABG procedure, extracorporeal circulation was introduced by inserting an arterial and a venous cannula into femoral vessels. Inserting the arterial cannula was hindered by the aforementioned advanced atherosclerotic changes. Despite several hours of reperfusion and the fact that the bleeding associated with the internal cardiac massage was controlled, the hemodynamic stability of the patient could not be maintained, and he died on the operating table.

\section{Discussion}

The literature concerning the development of aorto-coronary bypass aneurysms is relatively scarce. Notwithstanding, aneurysm etiology includes such factors as dyslipidemia, generalized atherosclerosis, and vessel wall fragility [4]. The natural progress of this pathology may be asymptomatic [5], and its diagnosis accidental, e.g. post-mortem [6].

The rare complication of CABG described above is diagnosed most often through non-specific medical history analysis (previous CABG employing venous material, dyspnea, fatigability) and physical examination revealing stasis in the veins of the upper half of the body and enlarged circumference of the face and the neck. In turn, additional examinations reveal the presence of a previously absent mediastinal mass [7] with location typical for venous bypass. In natural disease progression, its long duration favors the occurrence of fistulas between the bypass aneurysm and the left or right atrium, pulmonary artery, or the right ventricle [8].

\section{Conclusions}

In the case study described above, the cooperation between specialists in the fields of interventional cardiology and cardiac surgery was assumed immediately after reaching the final diagnosis. On its own, occluding the aneurysm with methods of interventional cardiology (coiling [9]) would not reduce the size of the mass or limit all the symptoms related to its presence (SVCS).

On the other hand, removing the degenerated bypass surgically without limiting the multidirectional arterial blood flow present within its lumen could have resulted in massive intraoperative bleeding [10]. Therefore, employing the approach established at the meeting of the heart team enabled the localization of the degenerated bypass as well as the visualization and reduction of blood flow through the bypass. The administration of thrombin during angiography facilitated the surgical dissection of the aneurysm and reduced the flow through its lumen to a bare minimum.

In spite of employing the described methods, the procedure was unsuccessful due to massive uncontrollable cardiac rhythm disruptions in the form of ventricular fibrillation. The ultimate result of the treatment was definitely influenced by numerous factors increasing the operative risk, which included: generalized atherosclerosis involving cephalad arteries and arteries of the lower extremities, enormous hypertension in the venous system (especially in the upper body), previous CABG with three bypasses remaining patent after 13 years and hindering surgical access, long-standing, though stabilized type II diabetes, and subclinical hypofunction of the thyroid gland.

In the event of a similar clinical case, extracorporeal circulation should be considered despite relative contraindications for its use in order to increase the safety of the performed procedure.

\section{References}

1. Favaloro RG. Saphenous vein autograft replacement of severe segmental coronary artery occlusion. Ann Thorac Surg 1968; 5: 334.

2. Ferrari ER, von Segesser LK. Arterial grafting for myocardial revascularization: how better is it? Curr Opin Cardiol 2006; 21: 584-588.

3. Jorapur V, Cano-Gomez A, Conde CA. Should saphenous vein grafts be the conduits of last resort for coronary artery bypass surgery? Cardiol Rev 2009; 17: 235-242

4. Neitzel GF, Barboriak JJ, Pintar K, Qureshi I. Atherosclerosis in aortocoronary bypass grafts. Morphologic study and risk factor analysis 6 to 12 years after surgery. Arteriosclerosis 1986; 6: 594-600.

5. Kriaa S, Zbidi M, Hafsa C, Braham N, Golli M, Gannouni A. Asymptomatic saphenous vein graft aneurysm. Ann Cardiol Angeiol (Paris) 2006; 55: 227-229. 
6. Tubbs RS, Salter EG, Sheetz J, Zehren S, Oakes WJ. An unusual case of a mediastinal mass in a cadaver. Clin Anat 2006; 19: 151-153.

7. Frank L, Mueller GC, Attili AK. AJR teaching file: a right paracardiac mass in a patient with a history of coronary artery bypass grafting. AJR Am J Roentgenol 2010; 195 (6 Suppl): S47.

8. Hickey EJ, Velissaris T, Tsang GM. A saphenous vein graft aneurysm with fistula development to the right atrium: surgical management of a rare bypass graft complication. Can J Cardiol 2008; 24: 915-916.

9. Dimitri WR, Reid AW, Dunn FG. Leaking false aneurysm of right coronary saphenous vein graft; successful treatment by percutaneous coil embolisation. Br Heart J 1992; 68: 619-620.

10. Murphy J, Shabb B, Nishikawa A. Rupture of an aortocoronary saphenous vein graft aneurysm. Am J Cardiol 1986; 58: 555-557. 